\title{
Jig Design for Welding of Wind Power Plant Component
}

Ivan Mrkvica ${ }^{1}$, Kamil Dihel ${ }^{1}$, Tomas Szotkowski ${ }^{1}$, Jozef Jurko ${ }^{2}$, Anton Panda ${ }^{2}$

${ }^{1}$ Faculty of Mechanical Engineering, VSB-Technical University of Ostrava, 17. listopadu 15/2172, 70833 Ostrava-Poruba, Czech Republic. E-mail: ivan.mrkvica@vsb.cz, K.Dihel@seznam.cz, tomas.szotkowski.st1@vsb.cz ${ }^{2}$ Faculty of Manufacturing Technologies with a seat in Presov, Technical University of Kosice, Sturova 31, 080 01 Presov, Slovakia. E-mail: jozef.jurko@tuke.sk, anton.panda@tuke.sk

Article deals with design of welding jig for assembly of wind power plant component. Mainstay of article is design of welding jig, which makes exactly setting and reliable clamping of individual parts of welded desing possible for their complete welding. Design procedure of individual parts of welding jig is described in details in view of their functionality. Paper is especially focused on the parts of welding jig, which are necessary to make, including material selection of individual parts. Finally the technical and economic evaluation is carried out, approximate cost of jig is calculated and financial savings associated with practical use of welding jig are evaluated.

Keywords: welding jig, basic board, setting and clamping, vertical clamp

\section{Acknowledgment}

This article has been solved in connection with projects Education system for personal resource of development and research in field of modern trend of surface engineering - surface integrity, reg. no. CZ.1.07/2.3.00/20.0037 financed by Structural Founds of Europe Union and from the means of state budget of the Czech Republic and by project Students Grant Competition SP2016/172 and SP2016/174 financed by the Ministry of Education, Youth and Sports and Faculty of Mechanical Engineering VŠB-TUO.

\section{References}

[1] MADDEN, J., STOWELL, M. P., WU, P., LI, H., HE, L. Welding Fixture with Active Position Adapting [Functions. Worchester polytechnic institute, [online] 2007 [cit. 2017-01-18]. Available: https://web.wpi.edu/Pubs/ Eproject/Available/E-project-082307102950/unrestricted/Welding_Fixture__ with_Active_Position_ Adapting_Functions.pdf]

[2] Mechanisation and Welding Fixture: ISF Aachen, [online]. 2002 Available: [http://mercury.kau.ac.kr/ welding/Welding\%20Technology\%20I\%2020Welding\%20Processes/Chapter\%2014\%20\%20Mechanisatio\% 20and\%20Welding\%20Fixtures.pdf].

[3] TOKAIENGENEERING PVD.LTD. Welding jigs and fixture. [online] 2016 [cit. 2017-01-18]. Available: [http://tokaiengineering.com/welding-jigs-and-fixtures.html]

[4] INDIAMART. Welding jigs. [online] 2016 [cit. 2017-01-18]. Available: [https://dir.indiamart.com/impact/welding-jigs.html]

[5] MRKVICA, I., SLEHA, V., PETRU, J., NESLUSAN, M., JURKO, J., PANDA, A. (2016). Design of control jig for inserts measurement. In: Manufacturing Technology, Vol. 16, No. 1, p. 198-204.

[6] MRKVICA, I., JANOS, M. (2010). Design of jig for turbo-blower support machining. In: Manufacturing technology, Sp. No., pp. 96-99.

[7] MRKVICA, I., CEP, R., SYSEL, P. (2010). Holding jig proposal for machining of hydraulic hose termination. In: Manufacturing technology, Vol. XV, No. 4, pp. 35-39.

[8] Hydac [online]. 2016 [cit. 2016-04-27]. Available: [http://www.hydac.com/czcs/oboryasystemy/obory/vetrnaenergie/obsah/ke-stazeni.html]

[9] PLUNDRICH, M. (2013). Construction design of manipulation device for welding robots. Master's thesis, Plzen: ZCU Plzen, 73 p. Available: [http://hdl.handle.net/11025/8720]

[10] DOLEZEL, J. (2014). Welding clamping device for the robot cell. Master's thesis, Brno: VUT Brno, 88 p.

[11] JANOVICOVA, J. (2014). Design of a welding jig for VW company. Master's thesis, Ostrava: VSB-TU Ostrava, $62 \mathrm{p}$.

[12] DIHEL, K. (2016). Design of jig production of welded component in company PSBLAS s.r.o. Master's thesis, Ostrava: VSB-TU Ostrava, $61 \mathrm{p}$. 
[13] Material Standards. Poltech [online]. 2013 [cit. 2016-04-28].Available: [http://www.poltech.cz/poltech/10Normy-CSN-DIN-ISO/15-Vlastnosti-oceli-10-19]

[14] Properties summary of S235JR steel. Bolzano [online]. 2005 [cit. 2016-04-28]. Available: [http://www.bolzano.cz/assets/files/TP/MOP_\%20Tycova_ocel/EN_10025/MOP_preled_vlastnosti_S235JR.pdf]

[15] Hooked adjustable clamp. D-S-C Czech Technology [online]. 2015 [cit. 2016-04-28]. Available: [http://dscczech.cz/destaco/hakovy-nastavitelny-upinac]

[16] Standard vertical clamps. D-S-C Czech Technology [online]. 2015 [cit. 2016-04-28]. Available: [http://dscczech.cz/destaco/vertikalne-upinace]

[17] Connecting/direct clamps. D-S-C Czech Technology [online]. 2015 [cit. 2016-04-28]. Available: [http://dscczech.cz/destaco/ojnicove-priamociare-upince]

Copyright (C) 2017. Published by Manufacturing Technology. All rights reserved. 